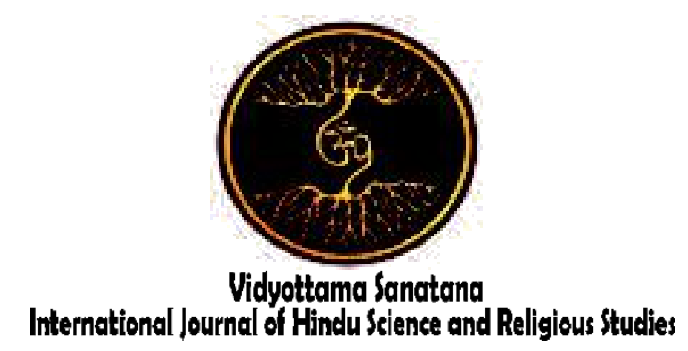

Vol. 4 No. 1 May 2020

\title{
MORAL CHARACTER EDUCATION IN EARLY CHILDHOOD IN THE HINDU FAMILY
}

\author{
By:
}

I Made Adi Widnyana ${ }^{1}$, Ida Bagus Komang Sindhu Putra², I Putu Adi Saskara ${ }^{3}$, Anak Agung Ngurah Budiadnyana ${ }^{4}$, I Nengah Juliawan ${ }^{5}$

${ }^{1234}$ Universitas Hindu Negeri I Gusti Bagus Sugriwa Denpasar

${ }^{5}$ STAHN Mpu Kuturan Singaraja

E-mail : ${ }^{1}$ adiwidnyana@ihdn.ac.id

Received: May 4, 2020

Accepted: May 21, 2020

Published: May 30, 2020

\begin{abstract}
This study aims to describe the moral character education in early childhood in the Hindu family. Education itself is the noblest thing in achieving physical and spiritual perfection, education, which should begin to be instilled as early as possible, starting moral character education cultivation from the smallest environment, namely the family. In the family, children feel a peaceful and harmonious environment. The results showed that moral character education in early childhood in the Hindu family, in the beginning, children were taught about how to live the greatness of God by carrying out prayers or Tri Sandya three times a day. It was along with the introduction of spiritual songs to develop good behaviors and strengthen their diversity.
\end{abstract}

Keywords: Moral Character Education; Early Childhood; Hindu Family

\section{INTRODUCTION}

Life cannot be separated from education since humans in the womb because the introduction of education begins with feelings and affection. Moral character education in the Hindu family should be instilled with affection. Reflected by role models of parents, siblings, and closest relatives. Moral character education leads towards etiquette and ethics in the life of a family and a wider environment, namely the community.

When moral characters' material is integrated or inserted into other subjects, which the subject that closest to the nature, character, or mission of this subject, such as Religious Education, Pancasila Education, 
and Civics Education (PPKn). This change reflects the nation's view towards moral character education, and at the same time, it reflects the thought struggle that has taken place since Indonesia's independence to the present. It also illustrates the change in the nation's concern for ethics-moral education represented by its curriculum structure.

Zuriah (2002) states that to realize National Education, Moral Character Education is integrated into several subjects relevant to the order and climate of socialcultural in the education world. The general aims are to facilitate students to be able to use knowledge, analyze, internalize, and personalizing values, developing social skills that enable them to grow and develop of noble character in students, and manifesting them in daily behavior, in various socio-cultural contexts that are diverse throughout life.

Furthermore, Cahyoto (2002) argues that to measure the noble character of a person based on the form of behavior that has no agreement among experts until now. One opinion states that moral character cannot be measured, while another states that moral character can be measured and assessed based on someone's behavior that has been done. The difficulty faced is not yet found a measuring tool that constantly and precisely measures behavior as a form of moral character. Measurements of someone's moral character carried out today will face two obstacles, namely moral characters that measured before has been developing and it differs from this day, and people's lives that affect moral character have also experienced development. The character guidance is essentially the practice of religion values. To make the guidance of character can be achieved in accordance with expectations, it is necessary to find the right pattern to be able to creat learners who have good moral and character (Sudarsana, Astawa, Arini, Jatiyasa, \& Suwendra, 2019).

Understanding the explanation above that a person's moral character cannot be measured by anything, however, giving moral character education from early childhood will support the development of children's lives, physically and mentally towards civilization in a general nature. Teaching the moral character is not only given since childhood, but children will grow to adulthood and the maturity level will affect the development of character, soul, and morals. This development is a reflection of parental guidance and selfawareness since being born in this world. A child born is entrusted by God to bring happiness to his parents, either joys or sorrow. It means that children should be devoted and well behaved, moral, and good manners. However, children do not always do good things, at times when their misbehavior peaks when parents do not pay close attention to them in their relationships, whether in the family, school, or community. Giving more attention to early childhood to get education, is one of the right steps to prepare a superior generation that will continue the nation's struggle. Early age is a golden age which only occurs once in the development of human life. This period is at the same time a critical period in child development. If at this time children receive less attention in terms of education, care, care and health services and their nutritional needs are feared that children cannot grow and develop optimally (Sudarsana, 2018).

The life of children in the family often ignores manners or courtesy when talking or behaving, as well as the child no longer listens to the parents' advice. Sometimes, the child is too brave towards his parents, ignoring everything and has no fear. The pathetic children's behavior can be seen from rarely the children asking for permission by lowering their heads and hands reaching down when passing in front of parents who are sitting. Parents often feel happy and satisfied when they see their child's got a good score at school, even though the child often says rude things. Rather than if the child has a good manner but he/she got a bad score at school, the parents often feel disappointed. Behavior at the dinner table is often ignored. There are no more expressions to invite or ask whether his brother has eaten or not. It causes for concern at the sight of early childhood who should be innocent and easy to manage, 
turned out to rebel and fight whenever their parents give advice. A thing that concerned the researcher, there were no longer greeting words or panganjali whenever the child came home or left home.

\section{Methods}

The type of this research was qualitative research. The qualitative approach in this study was used to examine purely and naturally matters relating to moral character education in early childhood in the Hindu family. The data of this research results were in the form of words or actions from the research subjects and it explained what happens in the field. After that, the data were analyzed inductively. To obtain objective data, the researcher functioned as a key (main) instrument that conducts direct observations and in-depth interviews of research subjects. Data collection methods using observation, interviews, and literature study. Data analysis in this research was carried out during and after data collection using qualitative data analysis flow models developed by Miles and Huberman (1992) which consisted of several stages activities, namely:

1. Data reduction is the process of sorting, focusing, abstracting, and transforming the rough data obtained, then sorted according to the focus of the study.

2. Data presentation is presented in the form of narrative description and synthesis, it does not rule out the possibility of argumentative forms expressed in providing interpretations.

3. Verification or drawing conclusions, the researcher tries to find meaning from the data obtained and look for explanations patterns, data configuration that has been verified, researchers draw conclusions.

\section{RESULTS AND DISCUSSIONS}

1. Implementation of Moral Character Education in the Hindu Family

Education lasts a lifetime known in the English proverb "Long Life Education" which illustrated that education is unlimited and endless, implied how human beings are expected to not be bored in exploring and pursuing education. Education can be obtained from the natural environment, namely from the family and formal environment (school). The success and failure of a study are dependent on the role of the family.

Furthermore, according to Hasan (2009), education must be done through three environments, namely family, school, and organization. Family is the first and most important center of education. Since the emergence of human civilization until now, the family always has a big influence on children's development. Education is a joint responsibility between family, community, and government. School as an assistant on continuing education in the family because people obtain their first and main education is in the family. Observing the explanation above that the role of the family as a booster in honing children's abilities through norms and values in the family, hence if things like this can be done, it will bring back the values of moral character education that have been sinking and marginalized from the education world. Therefore, education obtained in schools (formal) is only in the form of general knowledge while the teachings of kindness and good behavior can be found in non-formal education (family). The process of inculcating moral character education teaching should begin as early as possible, namely since early childhood because it is a vulnerable period. Children are most sensitive to stimuli that come whether from outside and the family, hence inculcating ethical values is required either in speaking or behaving.

The family, especially parents do have a vital role in the psychological development of children. If the child is psychologically in a fine state, then the possibility of the child bullying is very small. Conversely, if these family factors overshadow the psychological child to do bad things, children are vulnerable to becoming cyber bullying. From this we know that parents become the first stronghold for the child to not do bullying. The role of 
parents, schools, universities, and the community can help reduce / prevent the possibility of cyber bullying. This responsibility is given to parents to guide their children (Sudarsana, Yogantara, \& Ekawati, 2019).

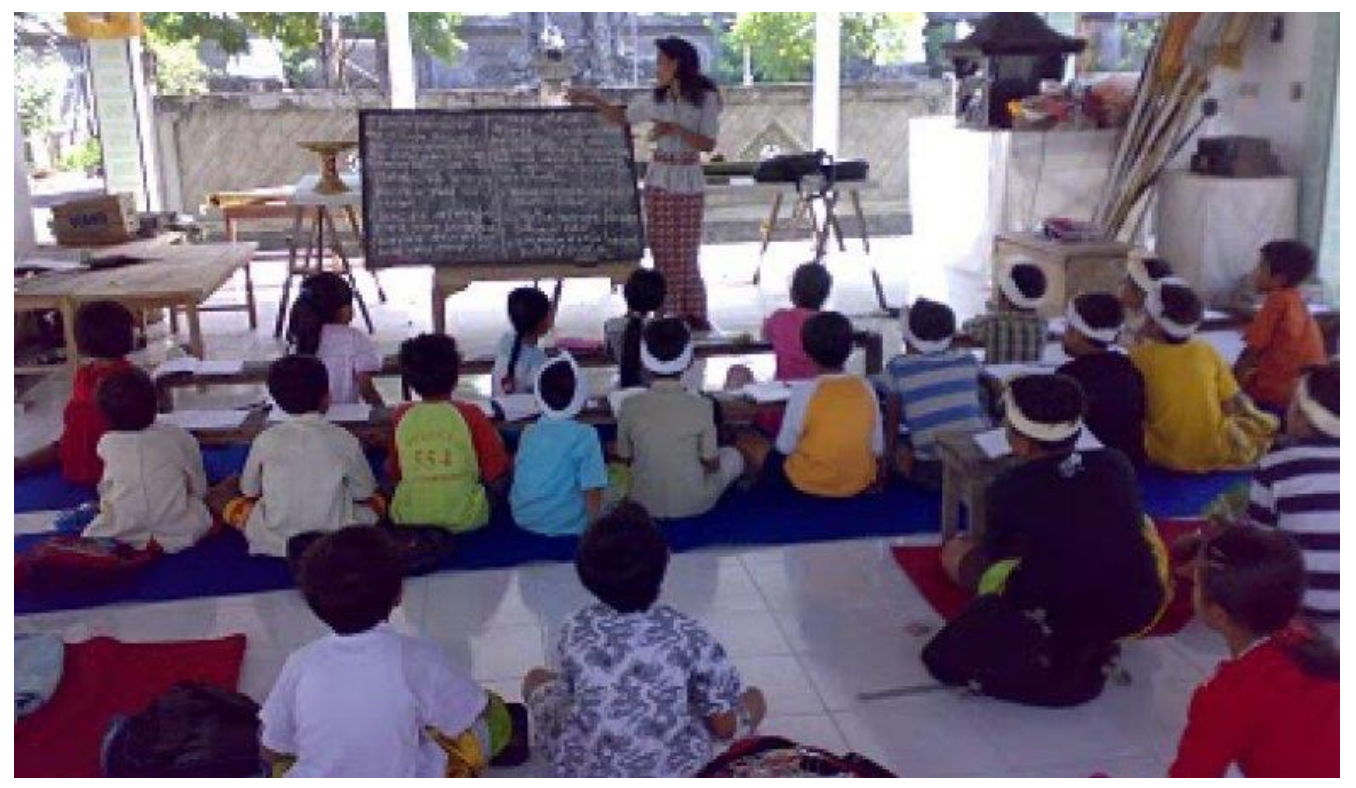

Figure 1 Pasraman in Cross-Age

(Source : https://phdi.or.id/artikel/pasraman-di-lintas-zaman)

Children education must be done through three environments, namely family, school, and organization. Family is the first and main center. Since the emergence of human civilization until now, the family always had a big influence on children's development. Education is a joint responsibility between family, community, and government. School as an assistant on continuing education in the family because people obtain their first and main education is in the family (Hasan, 2009).

The statement above asserts that education can be grouped into three stages, namely informal education, formal education, and non-formal education. Formal education is limited in providing value education due to the limited time between teacher and student. Nowadays, non-formal education in its development is very difficult to pay attention to children's development and value inculcation. Family is the first and main center of education as a place for someone to interact and obtain the foundations of good moral character. The education process in the family occurs naturally through the transformation of values which occurs slowly but systematically. It relates to the nature of values which are not first of all habits that lead to goodness.

In line with the explanation above, according to Suhartono, Fujiati \& Aflanie (2002), the family is the first environment that gives influence to various aspects of child development, including social development. Conditions and procedures of family life are a conducive environment for the child socialization. In the family, the norms of family life apply, and thus basically the family manipulates the cultural life of the child. The educational process aims to develop a child's personality which more determined by the family. The association patterns and how the norms in placing oneself in a wider environment which is set and directed by the family.

On the other hand, according to Noorlaila (2010), it is stated that the family is indeed a miniature of a broad society. Family is a place to prepare the scales, principles, and noble values of a society. It is under the family shelter, children will obtain and get a lesson 
about goodness. A child who does not get the parents' attention, it will make the child less confident and reserved. Therefore, a child's creativity becomes narrow, which raises doubts about his own abilities.

Furthermore, Titib (2003) explained that moral character education in the family is always integrated with various education received by a child in the house. Starting from getting up early, bathing, dressing, and praying before going to school and after returning from school. Parents, older siblings or anyone who lives together in the family should take responsibility for the success of education at home. A friendly and dialogic atmosphere can encourage the success of moral character education at home. In the initial phase, the thing that gets the most attention is role models, good examples from parents, and anyone who is older will brazing, fertilize the nursery, and develop the moral character education in children. Things that can be done, namely:

a. Teach children about manners and talks gentleness, not to be rude, curse, respect elders, and guests who come over.

b. Children are educated to always pray diligently, study hard, work hard, and foster honesty, and no stealing or hiding anything.

c. Familiarize children to always be open to parents when faced with a problem.

d. Developing affection for all beings, with small animals such as dragonflies, crickets, birds, fish, and butterflies.

e. Instill since early the habit of planting decorative plants, medicinal plants, and taking care of the house and garden by involving the child as the main actor.

f. Cultivating a clean lifestyle, cleaning the body, washing clothes, and ironing.

From an early age, children are taught to live independently and responsibly. Nowadays, the children life becomes uncertain due to the lack of moral character cultivation, thus school-age children are in association with fellow children who do not reflect noble character. Therefore, the family's responsibility to provide guidance, hence children can understand moral character teaching.

The problem of moral character, behavior, ethics cannot be left at school because school is only part of days in children's daily interactions, most of their times are spent in the family life. Therefore, a family is the application of the pioneers in the children's souls to behave and interact with their environment. In the family, the child will be obtained the truth values education, while school as a place to apply what is obtained at home.

Family is an informal education to build a child's character to be a suputra who is able to socialize by reflecting the truth values based on religious teachings. Moral character education and behavior are based on family education which influenced by the role of parents as teacher or guru rupaka. It is also a place to develop moral values, hence children can emulate the behavior of sanctified religious figures. Family or grahasta is the main key to build children's personalities who behave politely.

This is in line with the statement of Wiana (1997) that the family is the most important place for learning and implementing religious lessons properly and correctly, the root of community progress, country and the world is the progress of the family itself. In the family, people can learn such a way of life in a crowd without feeling sad or causing others to be sad, and we learn religion to utilize our life well. A family is a place for religious education to utilize life together to raise budhi, in order to increase the urge or tendency to live, therefore the moral quality and mental endurance increase.

\section{The Roles of Parents in the Implementation of Moral Character Education}

Parents are the main key in the context of inculcating moral character education for 
families. Thus, parents should have a commitment to pay attention to their children in relationships both in the family and surrounding environment, undoubtedly the children will develop well and have noble behavior. However, if parents do not have this commitment, do not pay attention and direct their children who in the end experience a decline in morality and character. In order to avoid the decline in morals and character of children, then the inculcating of moral character education teaching should begin as early as possible, namely since childhood because it is a vulnerable period. Children are most sensitive to stimuli that come whether from outside and the family, hence inculcating ethical values is required either in speaking or behaving.

Parents at home must present themselves as friends who can be invited to exchange ideas, hence communication between the child and parents runs well like running water smoothly with no obstruction. Building positive and constructive communication between parents and children is worth building, especially since the child is growing up. If the children have grown up, their treatment will change. The child no longer acts as a subordinate but he has a role as a friend who can be invited to having a discussion. If we have treated the child like that, undoubtedly there will be no problems hidden by the child anymore, if the child has a problem, he will be open to his parents. The open-minded attitude and the child will be easy for parents to detect early interference and barriers experienced by the child. Likewise with the children association that will be easily monitored, with whom he gets along with and what he does in the association. Because the wrong association will have an impact on children's daily behavior.

It turns out that the moral character education is a reflection of a Sradha, it will reflect the affection that is an aura of Ida Sang Hyang Widhi Wasa will be reflected on every child's behavior in the family environment. Speaks politely which is older than him always show affection for those nearby, even though the way of expression is still limited to kissing his parents' hands. Praying as a barometer of a person's Sradha level described in early childhood by imitating people's behavior in praying.

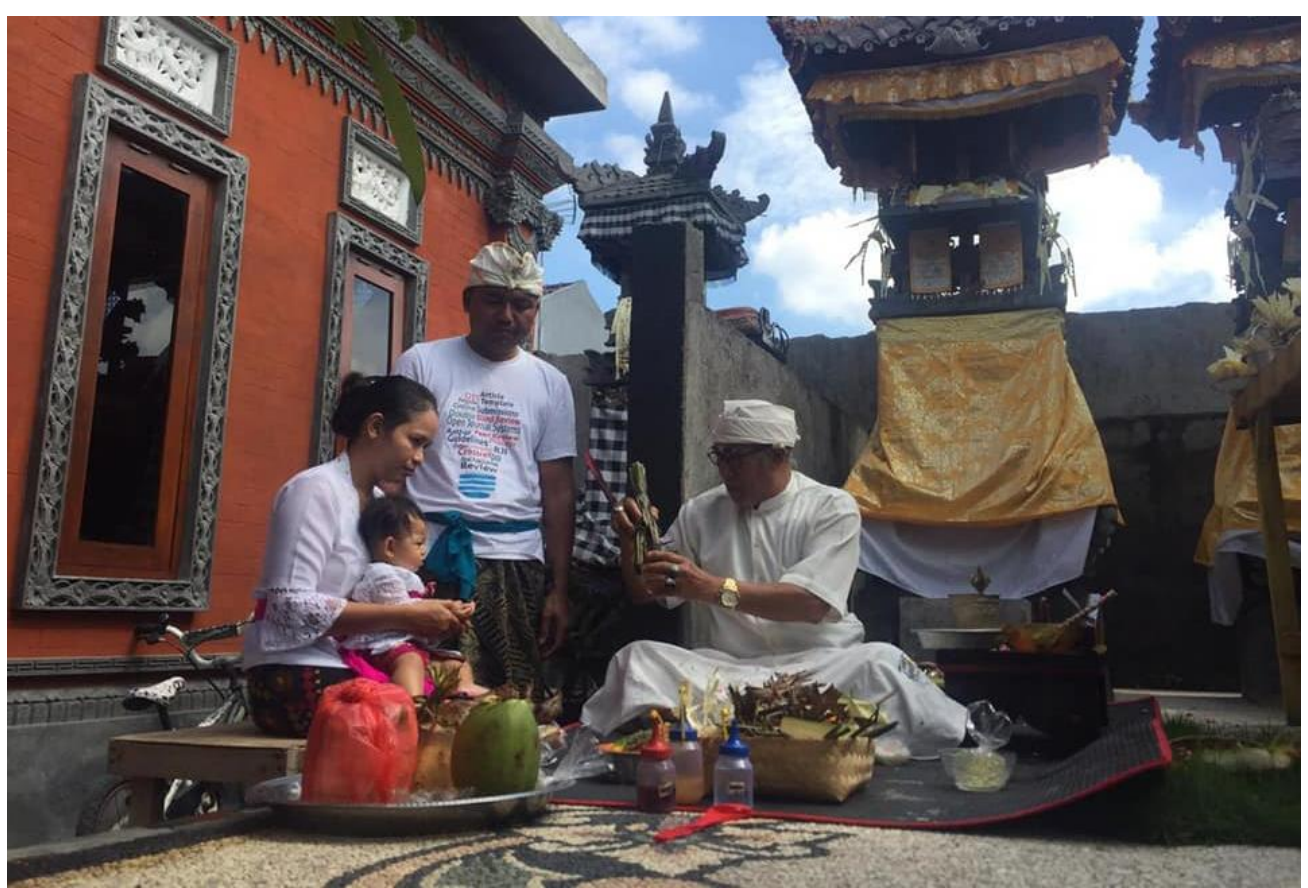

Figure 2 Ceremony For 6 Month Old Children

(Source : I Ketut Sudarsana Collection) 
In another part, the teaching of moral character is a matter that does not need to be discussed anymore, because it is fairness and obligation for fathers and mothers on providing guidance and education to their children. Thus, they become role models in their family life, especially if children are equipped with knowledge related to moral character education as early as possible. Because of the family as a place for them as long as you still alive and often expressed that family as the first and main place in forging themselves enjoy the bitterness of life.

Moral character education is a moral basis as a guide for behavior, hence the parents' expectation is to build noble character to their children in the globalization era these days and the wider community is concerned about moral character. The role of a person can be an example of behavior for the family members and instilling human values education. People should always establish good communication with family members using the mother tongue because the child begins to learn the language in which he was born.

The family is a place to foster and educate children, education in the family is indeed starting since he was in the womb until he knows the world. The family is the most ideal place to build a family. It is the first key figure in parenting a child to be a good child or suputra and becomes the parents' pride. In a family, children should be taught with the values of truth. Since he was born until the last day of his life, parents' education will be his karma responsibility.

Children are gift entrusted by Ida Sang Hyang Widhi Wasa, hence the parents' obligations to guide, educate children to become adults because whatever parents have done against children is a sacred note in undergoing karma. Parents should educate their children by giving examples in parenting their children because parents are figures admired and imitated by their children. Parents are friends where children can complain, and share their feelings. Parents play an important role in directing their children to the place they carry. If parents have a bad behavior, their children will imitate it and vice versa.

A wife is naturally closer to her children thus a mother can understand her children's feelings. Therefore, it will be easier to foster, guide and educate her children because with affection, children will be closer and understand what their parents mean.

It is appropriate for all parents to systematically parenting their children, it means that in parenting their children, parents must have programs both structured and unstructured. Structured means that parents share tasks in writing to their children in the family. Meanwhile, unstructured tasks are given to children and it delivers orally. By making this program, it will have a positive impact on children, especially in terms of responsibility, respect for parents' commands and tasks given. It because children are natural duplicates of parents, what they have done, implanted, fostered will be clearly illustrated in the child's behavior in daily life. The Balinese language is a pattern or system that in its use directly applies manners, courtesy in communicating with others.

\section{Parenting in Moral Character Education}

The pattern of parenting has a fundamental position in suppressing the occurrence of delinquency in the child, given that children spend their time in the family environment. The role of parents is necessary for improving family coaching. Therefore, parents have the opportunity to foster and develop the child's personality and character well. The environment is intensified, especially in communicating with children, hence the affection, attention, and direction can be delivered. Thus, the level of delinquency of the child can be reduced as least as possible.

Encouragement and optimal attention of parents to the success of children which include: finding a comfortable learning place, time distribution, preparing the necessary equipment, maintaining the child's relationships, and preparing a pleasant family atmosphere. 
Furthermore, according to Hasan (2009), the type or pattern of parenting can be classified into four parts, namely: (1) Authoritative Type; (2) Authoritarian Type; (3) Patients Type; (4) Abandonment Type. These types can be described as follows:

a. Authoritative Type

Authoritative parents will receive and involve the child fully. These parents have a high level of self-control and require their children to act at an intellectual and social level with their age and abilities. However, they still provide warmth, guidance, and provide two-way communication. They provide explanations and reasons for penalties and prohibitions. Children of these parents will grow into independent, self-assertive, friendly children with peers, and willing to work with parents. Children will also succeed intellectually and socially, enjoy their life, and have a strong motivation to progress (Hasan, 2009).

b. Authoritarian Type

Authoritarian type parents always demand and control because of power without warmth, guidance, and twoway communication. They control and assess children's behavior with absolute standards. They value obedience, respect for their power, and tradition. Children of these parents tend to have moderate competence and responsibility, tend to withdraw socially, and no spontaneity attitude. A girl will depend on their parents and do not have the motive to move forward. Meanwhile, a boy tends to be more aggressive than other boys, (Hasan, 2009).

c. Patients Type

Patient-type parents will accept, be responsive, gives little guidance to their children. Children will be more positive in their mood and show vitality than authoritarian children. Parents who are permissive will encourage children to be aggressive and tend to lack self-confidence (Hasan, 2009).

d. Abandonment Type

Abandonment type of parents pay more attention to their own activities and do not involve it to their children. They do not know where their children are, what they do, and who their friends when outside the house are. They are not interested in events in their children's school, they rarely converse with their children, and care about their children's opinions (Hasan, 2009).

The type or pattern of parenting according to the teachings of Hinduism is contained in the Slokantara Book which describing ethical teachings, texts, translations, and reviews (Sudharta, 1997), in sloka 22 (48) stated:

Kalingannya, dening anibākna warawarah ring anak, yan limang tahun tuwuhnya, kadi dening angiring anak sang prabhu dening anibākên warah iriya, matuha pwa ya ikang swaputra, katêka ring sadaša tahun tuwuhnya, irika tan yan warah hulun dening anibākên wara-warah iriya, kunang atuha ikang anak, katêka ring nêmbêlas tahun tuwuhnya, ika ta yan dadi dening amarah-marah ing mitra dening anibākên warah-warah iriya, mangkana krama ning marah-marah putra, ling sang hyang aji.

Translation:

Until the age of five, people must treat their children as king. In the next ten years as a servant and after the age of sixteen and above must be treated as a friend.

The statement above gives a signal about how to educate children from newborn $(0$ years) to adulthood (more than 15 years), even including when the child has entered the household level. According to Slokantara, parenting towards children's education can be divided into three stages, namely 0-5 years old, 6-15 years old and more than 15 years old by using the symbols of the words "king", "servant", and "friend". 
"King" is a special symbol given to things that must be prioritized or done as well as possible. Therefore, according to this educational concept, $0-5$ years aged children must be treated as well as possible, both physically and mentally. The best physical treatment is given through feeding, environment, touch, and others. Mental treatment is given by giving full recognition or respect which is manifested in the form of subtle words and polite behavior, a tangible manifestation of education. In Balinese (Hindu) society as follows: if there is a baby (toddler) held by an adult and the third person asked, then the babysitter will represent the baby responding to the questioner with the correct word or motion response, namely using soft words and limb movements in accordance with the values adopted, for example using the right hand.

According to Burn, servant "is a symbol for people who have no right to argue or comment. The 6-15 years aged children are psychologically in the transition period, namely has fickle-minded, not been able to make decisions responsibly, always willing to win themselves and other bad behavior. At that age, education must be given expressly and determined externally. Adults (parents, teachers) must give expressly what they must do. In formal education stated that teachers must determine what must be learned, when and where they learn (Subagia, 2007). At this stage, children are trained to be good servants, starting from serving their younger or older siblings, parents, and others who interact with them. Like a servant, a child at this stage is expected to be willing to do what has been told and always respect others, especially older people.

"Friend" is a symbol of equal people. Children after the age of 16 years or more are treated equally as adults. This is done considering that after 16 years of age, a child is old enough to distinguish between good and bad, appropriate and inappropriate based on the good experience he gained for 15 years. Modern education strongly recommends that children be given the opportunity to equalize themselves with adults, for example, it known as democratic education. The difference is in traditional education, democratization is only done after children able to interpret the word democracy, in western education it is recommended to be given since early education.

\section{CONCLUSION}

The implementation of moral character education in early childhood in the Hindu family is carried out to reflect good behavior among fellow children and parents. The connection with the implementation of moral character education in early childhood in the Hindu family is given materials related to the Tri Kerangka Agama Hindu including Tattwa, Etika, and Upacara. The material relating to Tattwa is Panca Sradha, related to ethics is Tri Kaya Parisudha, Catur Guru, Tri Parmartha, and Catur Paramitha. While those relating to Upacara are mekidung, prayer facilities, training in making prayer facilities and visiting holy sites.

\section{REFERENCES}

Cahyoto. (2002). Budi Pekerti dalam Perspektif Pndidikan. Malang: Depdiknas-Dirjen Pendidikan Dasar dan Menengah-Pusat Penataran Guru IPS dan PMP Malang.

Hasan Maimunah. (2009). Pendidikan Anak Usia Dini (PAUD). Yogjakarta: DIVA.

Miles, B M. dan Huberman. A M. (1992). Analisis Data Kualitatif. Jakarta: Universitas Indonesia Press.

Noorlaila. I. (2010). Panduan Lengkap Mengajar PAUD. Yogyakarta : Pinus

Subagia, I. W. (2007). Pengembangan model siklus belajar berdasarkan potensipotensi kearifan lokal masyarakat Bali dalam bidang pendidikan: studi pengembangan model siklus belajar berbasis budaya. Lembaga Penelitian, Universitas Pendidikan Ganesha.

Sudarsana, I. K., Yogantara, I. W. L., \& Ekawati, N. W. (2019). Cyber Bullying Prevention And Handling Through Hindu Family Education. Jurnal Penjaminan Mutu, 5(2), 170178. 
Sudarsana, I. K. (2018). Quality Improvement Of Early Childhood Education Through The Utilization Of Multimedia. Jurnal Penjaminan Mutu, 4(2), 174-183.

Sudarsana, I. K., Astawa, I. N. T., Arini, N. W., Jatiyasa, I. W., \& Suwendra, I. W. (2019, July). Maintaining Peace Among Students Through Character Building Based On The Values Of Pancasila (Five Principles). In $1 s t$ International Conference on Life, Innovation, Change and Knowledge (ICLICK 2018). Atlantis Press.

Sudharta. T. (2003). Slokantara Ajaran Etika, Teks, Terjemahan dan Ulasan. Surabaya : Paramita.
Suhartono, E., Fujiati, Aflanie, I. (2002). Oxygen Toxicity by Radiation and Effect of Glutamic Piruvat Transamine (GPT) Activity Rat Plasma after Vitamine C Treatmen. Diajukan pada Internatinal seminar on Environmental Chemistry and Toxicology. Yogyakarta.

Titib, I M. (2003). Menumbuhkembangkan Budhi Pekerti Pada Anak, Bandung : Ganesa Exact.

Wiana, I K. (1995). Yajna dan Bhakti Dari Sudut Pandang Hindu. Jakarta:Pustaka Manik Geni.

Zuriah, N. (2002). Revitalisasi-Radikalisasi Filsafat Dan Ideologi Pancasila Di Era Reformasi-Globalisasi. Malang: Univ.Muhammadiyah Malang 